\title{
Effect on Product Innovation and Marketing in Herbal City Community
}

\author{
Yananda Siraphatthada ${ }^{1}$, Duangkamol Thitivesa ${ }^{1} \&$ Parichart Rattanabunsakul $^{1}$ \\ ${ }^{1}$ Suan Sunandha Rajabhat University, Bangkok, Thailand \\ Correspondence: Yananda Siraphatthada, Suan Sunandha Rajabhat University, Bangkok, Thailand. E-mail: \\ yananda.si@ssru.ac.th
}

Received: July 17, 2020

Accepted: September 4, 2020

Online Published: September 23, 2020

doi:10.5430/rwe.v11n6p63

URL: https://doi.org/10.5430/rwe.v11n6p63

\begin{abstract}
Number of studies has carried out the research studies on product success among various industries. However, the product success is not discussed in respect to the herbal city community. Therefore, to fill this research gap, objective of this study is to investigate the role of product innovation and marketing practices in product success of herbal city community. Population of the study is herbal companies of Thailand. Data were collected from the herbal companies in Thailand. Employees of herbal companies were selected as the respondents. Data shows that both product innovation and marketing practices has significant role to enhance product success. Increase in product innovation and marketing practices increases the product success. Product innovation and marketing practices effect positively on customer retention and marketing practices respectively which causes to increase product success.
\end{abstract}

Keywords: product innovation, marketing practices, customer retention, marketing practices, product success

\section{Introduction}

Product success has vital role among the companies because product success is the guaranty of higher performance by the companies. Majorly, the company's success is dependent on the product success. Better the product success better will be the performance as it is mentioned by the previous investigations on product success and performance (Rothaermel, Hitt, \& Jobe, 2006). Success of product is based on the various important factors which contribute to company performance. Better product success increases the sale of the product which causes to increase in the revenue of the companies and finally increase the performance.

All sorts of companies are dependent on the product success. Along with the other companies, herbal medicine companies also have important role to get success in various products. Herbal companies have many products related to the medicine which has vital importance for the company's success. New product development among the herbal companies is important because new product success in herbal medicine companies play an important role to capture the market share. Not only herbal medicine companies, product success is also key in other companies for better performance. The Herbal companies are growing among various countries in the field of producing medicines because herbal medicines has several benefits (Lin, Huang, Lin, \& Huang, 2020), particularly, these medicines do not has side effects as compared to the other medicines.

These herbal companies in the field of medicine are also increasing in Thailand. The number of herbal companies in respect to the other medicine companies is increasing and contribution to the market of medicine industry which has influence on pharmaceutical companies. Various countries are investing heavily on healthcare industry. In the field of healthcare industry, countries are also investing in herbal companies. Therefore, total investment is the combination of both herbal and other medicine sector. Figure 1 shows that United States of America (USA) is investing more as compares to the other countries in the healthcare sector. Moreover, after the USA, Sweden is also investing majorly in healthcare. Various other developed countries such as United Kingdom (UK) and Germany is investing majorly on healthcare. Thailand is also investing in both herbal and other healthcare sector, however, this investment is not very high like other mentioned countries. Therefore, the importance of herbal companies cannot be neglected (Ma \& Cheng, 2020; Marquez, Lingat, Silva, Rodriguez, \& de Vera, 2020; Melesse, 2019; Mensah, Jianlin, \& Jun, 2019; Muhammad Auwal, Mohamed, Nasir Shamsudin, Sharifuddin, \& Ali, 2020; Muzurura, 2019). As the herbal industry is producing various products which has contribution to various economic activities. Thus, along with healthcare benefits, herbal companies are also contribution to the field of economic development all over the world. These companies also have contribution to the development of Thai economic activities. 


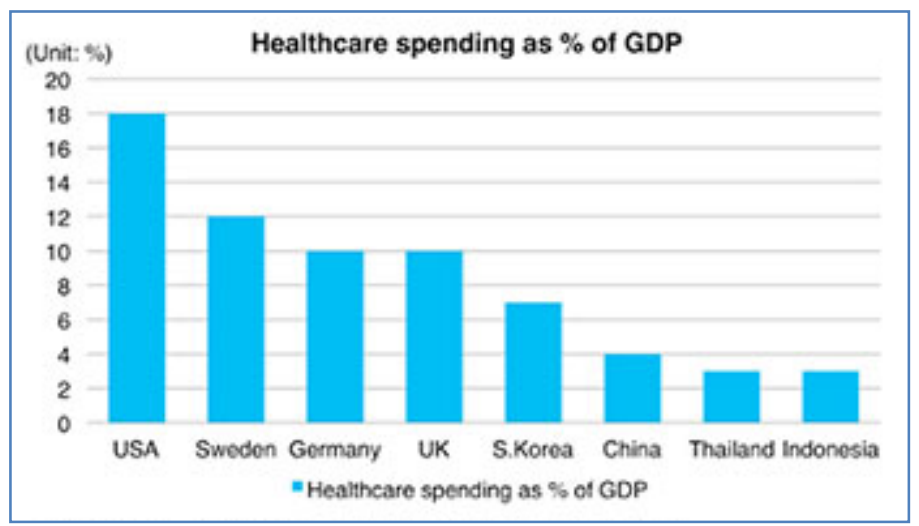

Figure 1. Healthcare spending and selected economics

Growing importance of these companies in Thailand is dependent on the product success. Product success in respect to the Thai herbal companies is based on the new medicine developed by these companies for healthcare product. These companies must have better product success rate in the market. All medicine companies always try to enhance their performance by increasing the new product development. However, new product development is not sufficient, it also needs success of the product in the market. In Thailand, most of the herbal companies has low performance, the responsible factor of low performance is product success. Decline in product success decline the performance. Hence, product success in medicine companies has vital importance (Shahmohammadi \& Khanaposhtani, 2016).

There are several factors influencing the new products of medicine companies. In other words, the product success is based on several factors. According to the current study, there are two major factors effecting product success among herbal companies. These factors include; product innovation and marketing practices. Both product innovation and marketing practices has major importance for the product success. Better innovative product and marketing practices increase the success rate of herbal company products. As it is given in previous studies that product innovation and marketing practices has role in product success or performance (Walton, Petrovici, \& Fearne, 2017). According to the current study, product innovation effect positively on customer retention which causes to increase product success. Moreover, marketing activities increases the product awareness among the customer which also increases the product success.

Therefore, objective of this study is to investigate the role of product innovation and marketing practices in product success of herbal city community. This study examined the relationship between product innovation, marketing practices, customer retention, product awareness and product success among the herbal companies of Thailand. Previous studies examined the product success (Abid et al., 2018; Marchand, Hennig-Thurau, \& Wiertz, 2017; Nguyen, 2020), however, these studies missed the role of product success in herbal city community in Thailand. Hence, this study filled this gap by examining the relationship between product innovation, marketing practices, customer retention, product awareness and product success among the herbal companies of Thailand.

\section{Literature Review}

Herbal medicine is the study of botany as well as the use of medicinal plants. Plants have been the foundation for medical treatments through much of human history, as well as such traditional medicine is still extensively practiced today. Along with the other medicine, herbal medicine also has important role which has contribution to the field of medicine. Most of the herbal medicine also has pivotal role to save the lives of the human. Valuable herbal products must be promoted to enhance the facility for the people. It also decreases the burden on the hospitals and other medicine companies. Previous studies also show the importance of herbal medicines (Hawrelak et al., 2020; Njegovanovic, 2018; Pferschy-Wenzig et al., 2017). To enhance the performance of herbal companies, the product performance is most important. Better herbal product performance is important to enhance overall herbal city community performance. Number of factors effecting on the product performance of herbal city community. Especially, product innovation has vital relationship with product retention and customer retention has relationship with product success. Along with this, marketing practices also has important role to promote herbal product success. It has especial role on product awareness and product awareness has positive role in product success. Therefore, product innovation and marketing practices has important role in product success of herbal city community. As studies highlighted by literature that product innovation and marketing is important in performance (Tundung, Ludfi, 
\& Hanif, 2017). The relationship between product innovation, marketing practices, customer retention, product awareness and product success are given in Figure 2.

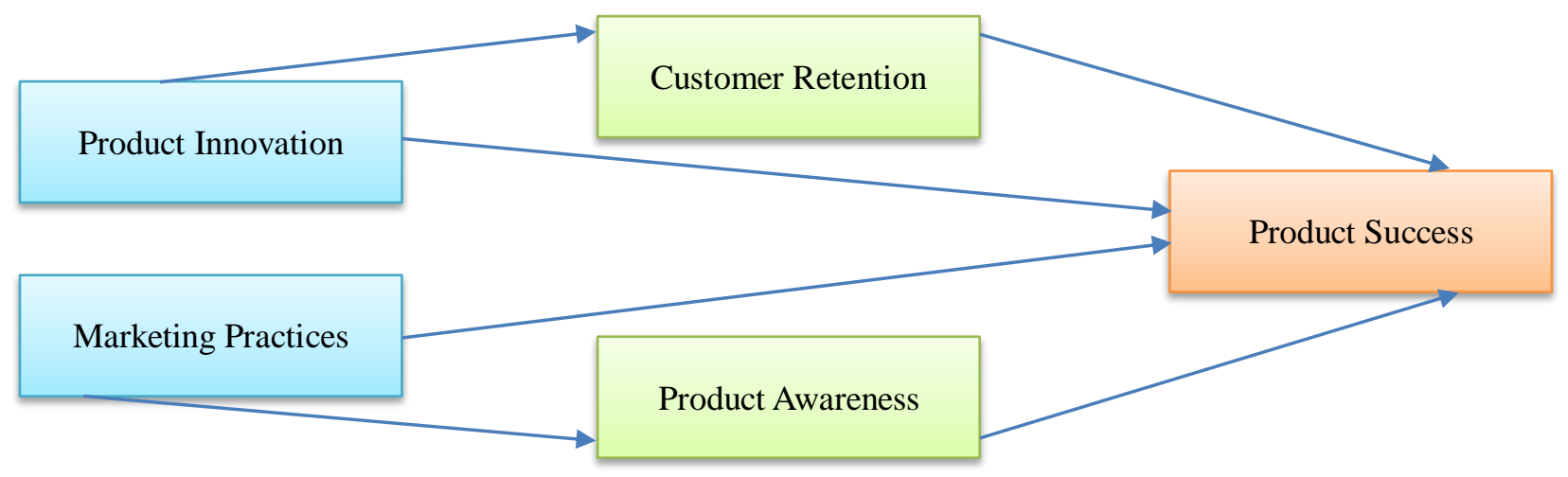

Figure 2. Theoretical framework of the study showing the relationship between product innovation, marketing practices, customer retention, product awareness and product success

\subsection{Product Innovation and Product Success}

Product innovation can be explained as: the growth of new products, changes in strategy of reputable products, or use of new materials or mechanisms in the manufacture of traditional products. Many examples of product innovation comprise introducing new products, improved quality as well as improving its overall performance. Product innovation has key role in success of any product. Because better innovation in the product has the ability to attract the customers. It also has the ability to retain the customers. Most of the companies including medicine companies always try to enhance innovation. Many of the studies shows the effect of product innovation in product performance or success (Michaelis \& Markham, 2017; Najafi-Tavani, Najafi-Tavani, Naudé, Oghazi, \& Zeynaloo, 2018; Walton et al., 2017). There results lead to the following hypothesis;

Hypothesis 1. Product innovation has positive influence on product success.

\subsection{Marketing Practices and Product Success}

Marketing is one of the important strategies which has influence on product success. Better strategies by the companies has positive role to enhance product performance. Most of the companies use better marketing strategies to enhance the new product promotion. Even the product innovation also needs the support of marketing strategies to penetrate in the market. Low level marketing strategies shows negative effect on the sale of the product by decreasing the product success. Therefore, effective marketing strategies are required to promote product success. Thus, herbal community should also have better marketing practices to enhance product success. As better marketing practices has positive role in product success or performance which is shown in previous studies (Falahat, Ramayah, Soto-Acosta, \& Lee, 2020; Souder \& Song, 1997).

Hypothesis 2. Marketing practices has positive influence on product success.

\subsection{Product Innovation and Customer Retention}

Customer retention denotes to the activities as well as actions companies and different organizations take to decrease the number of customer defections. The objective of customer retention agendas is to help different companies retain various customers as possible, often with the help of customer loyalty as well as brand loyalty initiatives. In customer retention, product innovation has vital role (Ali, Naveed, ul Hameed, \& Rizvi, 2018; Hamid, Shahid, Hameed, Amin, \& Mehmood, 2019; Noor \& Siddiqui, 2019; Razzaq, Maqbool, \& Hameed, 2019). Better innovation in the products has positive role in customer retention. As better innovations in the product is one of the good sources of customer attraction. Increase in innovation increases the customer attraction which causes to increase the customer retention. The relationship between customer retention and product innovation is already given in literature (Andriyani et al., 2017; Querbach, Bird, Kraft, \& Kammerlander, 2020).

Hypothesis 3. Product innovation has positive influence on customer retention. 


\subsection{Marketing Practices and Product Awareness}

Marketing is the important element of business study and field of management of exchange relationships among people in business terms. It is the business procedure of classifying, anticipating as well as satisfying customers' wants. Because marketing is used to appeal customers, it is the main components of business management as well as commerce. It has most significant relationship with product awareness. Because a new product in the market always requires various marketing activities for the customers which develop good image and provide the information regarding the new features of the product. True information to the general people can increase the attraction among people. This relationship between marketing practices and product awareness is discussed in the previous studies (Suki \& Suki, 2019; Sürücü, Öztürk, Okumus, \& Bilgihan, 2019).

Hypothesis 4. Marketing Practices has positive influence on product awareness.

\subsection{Customer Retention and Product Success}

It is discussed above that product innovation has significant role in product success and customer retention. Marketing practices has positive role in product success and product awareness. This section shows that customer retention has important role in product success. One-time purchase of product by the customer cannot achieve the desired goal of product success, therefore, a customer must purchase a product more than one time which is possible through customer retention. Therefore, customer retention strategies are important to enhance product success which is also clear from other studies that performance or success has relationship with customer retention (Almohaimmeed, 2019; Omondi \& Odock, 2019).

Hypothesis 5. Customer retention has positive influence on product success.

\subsection{Product Awareness and Product Success}

Awareness is the state of being aware of something. More precisely, it is the capability to directly know as well as perceive, to feel, or to be cognizant of events. Product awareness is related to the customers information about the product. Therefore, it can be defined as the customer information about the features of a specific product. Customers always require information before to purchase the product. Therefore, information by the customers related to the product causes to purchase by the customer. Therefore, product awareness has role in product success which is also mentioned in the previous studies (Wu, Joung, \& Lee, 2013).

Hypothesis 6. Product awareness has positive influence on product success.

Hypothesis 7. Customer retention mediates the relationship between product innovation and product success.

Hypothesis 8. Product awareness mediates the relationship between marketing practices and product success.

\section{Research Methodology}

Research methodology is the way to conduct a research study. It is one of the systematic ways to carry out research through formal process. The current study also followed a systematic way to achieve the objective of this study. In this way, this study designed a survey questionnaire (Bowling, Bond, Jenkinson, \& Lamping, 1999) which is an effective instrument of data collection. Hence, a questionnaire was preferred, thus, this study is quantitative in nature. Number of studies have followed survey questionnaires for data collection and recommended most suitable tool in primary data studies.

To measure the relationship between product innovation, marketing practices, customer retention, product awareness and product success, this study conducted a survey among herbal companies of Thailand. 450 survey questionnaires were sent to the Thailand herbal companies. By using the simple random sampling (Siuly, Li, \& Wen, 2011), questionnaires were distributed among the herbal city community of Thailand. All the companies of herbal community were targeted by the current study. Objective of the study was discussed to the respondents before data collection. Therefore, respondents were confident to fill the survey questionnaires as the researcher was insured that their response will only use for academic purposes.

\section{Findings}

Table 1 shows the missing value in the data. Outlier in the data is also given in Table 1. Along with this, data mean, median and standard deviation is given. Additionally, data normality is given. According to the previous studies on errors in the data, it is clear that missing value should be removed from the data (Aydin \& ŞENOĞLU, 2018). Outlier is not found in the data. Finally, data normality is not required while using Partial Least Square (PLS). 
Table 1. Data statistics

\begin{tabular}{|c|c|c|c|c|c|c|c|c|c|}
\hline & No. & Missing & Mean & Median & Min & Max & SD & Kurtosis & Skewness \\
\hline PI1 & 1 & 0 & 3.263 & 3 & 1 & 7 & 1.399 & 0.214 & 0.722 \\
\hline PI2 & 2 & 0 & 3.089 & 3 & 1 & 6 & 0.179 & 1.287 & 1.495 \\
\hline PI3 & 3 & 0 & 3.474 & 4 & 1 & 7 & 1.342 & -0.284 & -0.193 \\
\hline PI4 & 4 & 0 & 3.5 & 4 & 1 & 7 & 1.362 & 1.006 & 0.016 \\
\hline PI5 & 5 & 0 & 3.513 & 4 & 1 & 7 & 0.626 & -0.515 & 0.154 \\
\hline PI6 & 6 & 0 & 3.026 & 3 & 1 & 7 & 1.936 & -1.124 & 1.253 \\
\hline PI7 & 7 & 0 & 3.461 & 3 & 1 & 7 & 1.976 & -0.99 & 0.368 \\
\hline MP1 & 8 & 0 & 3.421 & 3 & 1 & 7 & 1.794 & -0.733 & 0.348 \\
\hline MP2 & 9 & 0 & 3.447 & 4 & 1 & 7 & 0.517 & -0.669 & 0.056 \\
\hline MP3 & 10 & 0 & 3.087 & 4 & 1 & 7 & 1.721 & -0.667 & 1.157 \\
\hline MP4 & 11 & 0 & 3.566 & 4 & 1 & 7 & 1.802 & -1.065 & 0.277 \\
\hline MP5 & 12 & 0 & 3.553 & 4 & 1 & 7 & 1.617 & -0.539 & 0.151 \\
\hline MP6 & 13 & 0 & 3.592 & 4 & 1 & 7 & 0.822 & -0.816 & 0.242 \\
\hline CR1 & 14 & 0 & 3.045 & 4 & 1 & 7 & 1.804 & -0.913 & 0.137 \\
\hline CR2 & 15 & 0 & 3.579 & 4 & 1 & 7 & 1.656 & -0.753 & -0.044 \\
\hline CR3 & 16 & 0 & 3.487 & 4 & 1 & 7 & 1.69 & -0.559 & 0.148 \\
\hline CR4 & 17 & 0 & 3.237 & 2 & 1 & 7 & 2.288 & -1.096 & 0.644 \\
\hline PA1 & 18 & 0 & 3.289 & 2 & 1 & 7 & 2.421 & -1.338 & 0.561 \\
\hline PA2 & 19 & 0 & 3.145 & 2 & 1 & 7 & 2.211 & -0.973 & 0.693 \\
\hline PA3 & 20 & 0 & 3.092 & 2 & 1 & 7 & 2.184 & -0.857 & 0.731 \\
\hline PA4 & 21 & 0 & 3.158 & 2 & 1 & 7 & 2.428 & -1.221 & 0.678 \\
\hline PS1 & 22 & 0 & 3.105 & 2 & 1 & 7 & 2.18 & -0.85 & 0.772 \\
\hline PS2 & 23 & 0 & 2.987 & 2 & 1 & 7 & 1.909 & -0.497 & 0.737 \\
\hline PS3 & 24 & 0 & 2.908 & 2 & 1 & 7 & 2.097 & -0.624 & 0.814 \\
\hline PS4 & 25 & 0 & 3.145 & 2 & 1 & 7 & 2.344 & -1.112 & 0.692 \\
\hline PS5 & 26 & 0 & 3.421 & 2 & 1 & 7 & 2.273 & -1.246 & 0.506 \\
\hline PS6 & 27 & 0 & 3.079 & 2 & 1 & 7 & 2.205 & -0.826 & 0.754 \\
\hline
\end{tabular}

Note: PI = Product Innovation; MP = Marketing Practices; CR = Customer Retention; PA = Product Awareness; PS $=$ Product Success

It is given in the Figure 3 that product innovation is measured with the help of seven scale items. The factor loadings of these items were observed which shows that all the item has factor loadings above 0.7, except two items. Two items have factor loadings below 0.7 but above 0.6. Studies also accept factor loadings above 0.5. Marketing practices are measured by using six items and shows that all items are above 0.7 . Customer retention is measured by using three items and all are above 0.7. Product awareness is measured by using four items and finally, product success is measured by using six items with all items above 0.7. Hence, all the items of all variables; product innovation, marketing practices, customer retention, product awareness and product success have factor loadings above 0.6 which is acceptable. This study used confirmatory factor analysis (CFA) to examine factor loadings (F. Hair Jr, Sarstedt, Hopkins, \& G. Kuppelwieser, 2014; J. F. Hair, Ringle, \& Sarstedt, 2013; Hair Jr, Hult, Ringle, \& Sarstedt, 2016; Hameed, Basheer, Iqbal, Anwar, \& Ahmad, 2018). 


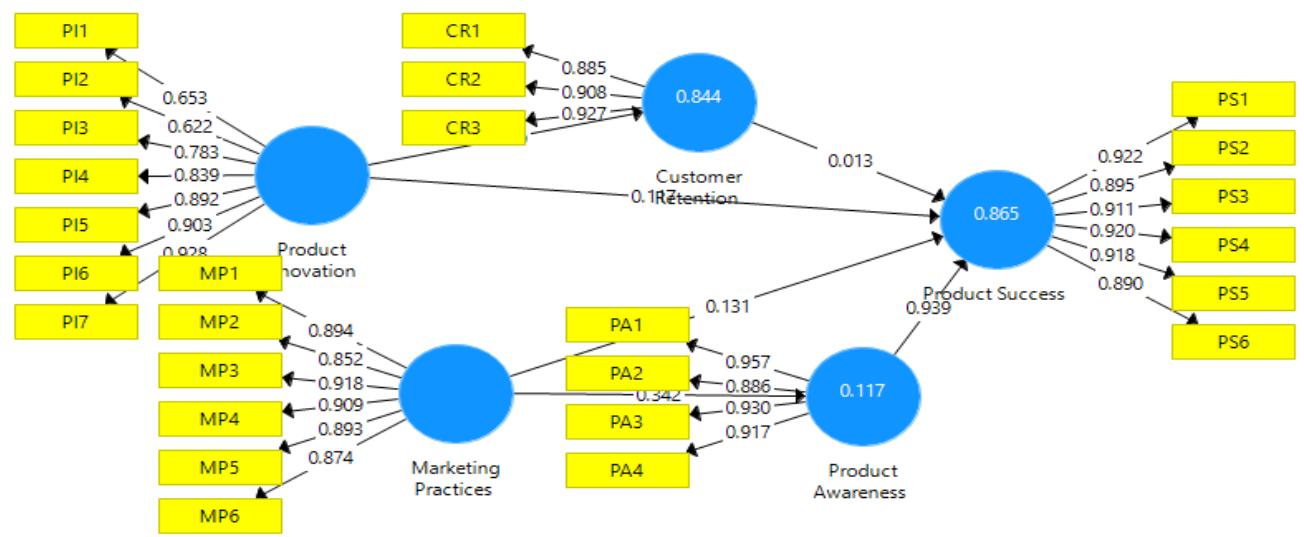

Figure 3. Measurement model

Table 2. Factor loadings

\begin{tabular}{|c|c|c|c|c|c|}
\hline & $\begin{array}{l}\text { Customer } \\
\text { Retention }\end{array}$ & $\begin{array}{c}\text { Marketing } \\
\text { Practices }\end{array}$ & $\begin{array}{c}\text { Product } \\
\text { Awareness }\end{array}$ & $\begin{array}{c}\text { Product } \\
\text { Innovation }\end{array}$ & $\begin{array}{l}\text { Product } \\
\text { Success }\end{array}$ \\
\hline CR1 & 0.885 & & & & \\
\hline CR2 & 0.908 & & & & \\
\hline CR3 & 0.927 & & & & \\
\hline MP1 & & 0.894 & & & \\
\hline MP2 & & 0.852 & & & \\
\hline MP3 & & 0.918 & & & \\
\hline MP4 & & 0.909 & & & \\
\hline MP5 & & 0.893 & & & \\
\hline MP6 & & 0.874 & & & \\
\hline PA1 & & & 0.957 & & \\
\hline PA2 & & & 0.886 & & \\
\hline PA3 & & & 0.93 & & \\
\hline PA4 & & & 0.917 & & \\
\hline PI1 & & & & 0.653 & \\
\hline PI2 & & & & 0.622 & \\
\hline PI3 & & & & 0.783 & \\
\hline PI4 & & & & 0.839 & \\
\hline PI5 & & & & 0.892 & \\
\hline PI6 & & & & 0.903 & \\
\hline PI7 & & & & 0.928 & \\
\hline PS1 & & & & & 0.922 \\
\hline PS2 & & & & & 0.895 \\
\hline PS3 & & & & & 0.911 \\
\hline PS4 & & & & & 0.92 \\
\hline PS5 & & & & & 0.918 \\
\hline PS6 & & & & & 0.89 \\
\hline
\end{tabular}

Note: PI = Product Innovation; MP = Marketing Practices; $\mathrm{CR}=$ Customer Retention; PA = Product Awareness; PS $=$ Product Success 
Further to assess the measurement model, this study examined composite reliability (CR) and average variance extracted (AVE). Table 3 shows the results of CR and AVE. It is evident that CR is above 0.7. As J. Hair, Hollingsworth, Randolph, and Chong (2017) recommended that CR must be above 0.7. Furthermore, product innovation, marketing practices, customer retention, product awareness and product success have AVE above 0.5. Along with this, discriminant validity is given in Table 3.

Table 3. Reliability and convergent validity

\begin{tabular}{lcccc}
\hline & Alpha & rho_A & CR & (AVE) \\
\hline Customer Retention & 0.892 & 0.892 & 0.933 & 0.822 \\
Marketing Practices & 0.948 & 0.96 & 0.958 & 0.793 \\
Product Awareness & 0.942 & 0.943 & 0.958 & 0.852 \\
Product Innovation & 0.911 & 0.936 & 0.929 & 0.658 \\
Product Success & 0.958 & 0.959 & 0.966 & 0.827 \\
\hline
\end{tabular}

Note: PI = Product Innovation; MP = Marketing Practices; CR = Customer Retention; PA = Product Awareness; PS

$=$ Product Success

Table 4. Cross-loadings

\begin{tabular}{lccccc}
\hline & $\begin{array}{c}\text { Customer } \\
\text { Retention }\end{array}$ & $\begin{array}{c}\text { Marketing } \\
\text { Practices }\end{array}$ & $\begin{array}{c}\text { Product } \\
\text { Awareness }\end{array}$ & $\begin{array}{c}\text { Product } \\
\text { Innovation }\end{array}$ & $\begin{array}{c}\text { Product } \\
\text { Success }\end{array}$ \\
\hline CR1 & 0.885 & 0.859 & 0.36 & 0.811 & 0.3 \\
CR2 & 0.908 & 0.855 & 0.326 & 0.827 & 0.289 \\
CR3 & 0.927 & 0.821 & 0.271 & 0.86 & 0.234 \\
MP1 & 0.831 & 0.894 & 0.325 & 0.87 & 0.253 \\
MP2 & 0.771 & 0.852 & 0.203 & 0.794 & 0.209 \\
MP3 & 0.834 & 0.918 & 0.365 & 0.805 & 0.316 \\
MP4 & 0.868 & 0.909 & 0.291 & 0.83 & 0.243 \\
MP5 & 0.779 & 0.893 & 0.275 & 0.808 & 0.232 \\
MP6 & 0.885 & 0.894 & 0.328 & 0.828 & 0.248 \\
PA1 & 0.338 & 0.332 & 0.957 & 0.31 & 0.878 \\
PA2 & 0.32 & 0.291 & 0.886 & 0.315 & 0.847 \\
PA3 & 0.266 & 0.287 & 0.93 & 0.255 & 0.826 \\
PA4 & 0.37 & 0.349 & 0.917 & 0.347 & 0.875 \\
PI1 & 0.468 & 0.501 & 0.318 & 0.853 & 0.28 \\
PI2 & 0.425 & 0.496 & 0.281 & 0.822 & 0.243 \\
PI3 & 0.75 & 0.721 & 0.113 & 0.883 & 0.102 \\
PI4 & 0.83 & 0.822 & 0.243 & 0.889 & 0.276 \\
PI5 & 0.809 & 0.776 & 0.309 & 0.892 & 0.29 \\
PI6 & 0.88 & 0.9 & 0.321 & 0.903 & 0.261 \\
PI7 & 0.883 & 0.889 & 0.336 & 0.928 & 0.258 \\
PS1 & 0.232 & 0.212 & 0.831 & 0.249 & 0.922 \\
PS2 & 0.207 & 0.174 & 0.788 & 0.194 & 0.895 \\
PS3 & 0.32 & 0.321 & 0.86 & 0.303 & 0.911 \\
PS4 & 0.308 & 0.303 & 0.882 & 0.297 & 0.92 \\
PS5 & 0.266 & 0.255 & 0.883 & 0.259 & 0.918 \\
PS6 & 0.311 & 0.285 & 0.816 & 0.311 & 0.89 \\
\hline
\end{tabular}

Note: PI = Product Innovation; MP = Marketing Practices; CR = Customer Retention; PA = Product Awareness; PS $=$ Product Success 
After the systematic assessment of reliability and validity, further this study examined PLS structural model (Henseler \& Fassott, 2010; Henseler, Ringle, \& Sinkovics, 2009; Richter \& Walther, 2016). The direct effect of product innovation was examined on product success and customer retention. The direct effect of marketing practices was examined on product awareness and product success. Process of PLS structural model is given in Figure 4 and Table 5 shows the results which indicated that product innovation has positive effect on product success. It also has significant positive effect on customer retention. Thus, increase in product innovation increases the product success and customer retention. Moreover, marketing practices has positive effect on product success. It also has significant positive effect on product awareness. Thus, increase in marketing practices increases the product success and customer retention. Further to this, it is found that customer retention and product awareness has positive influence to enhance product success.

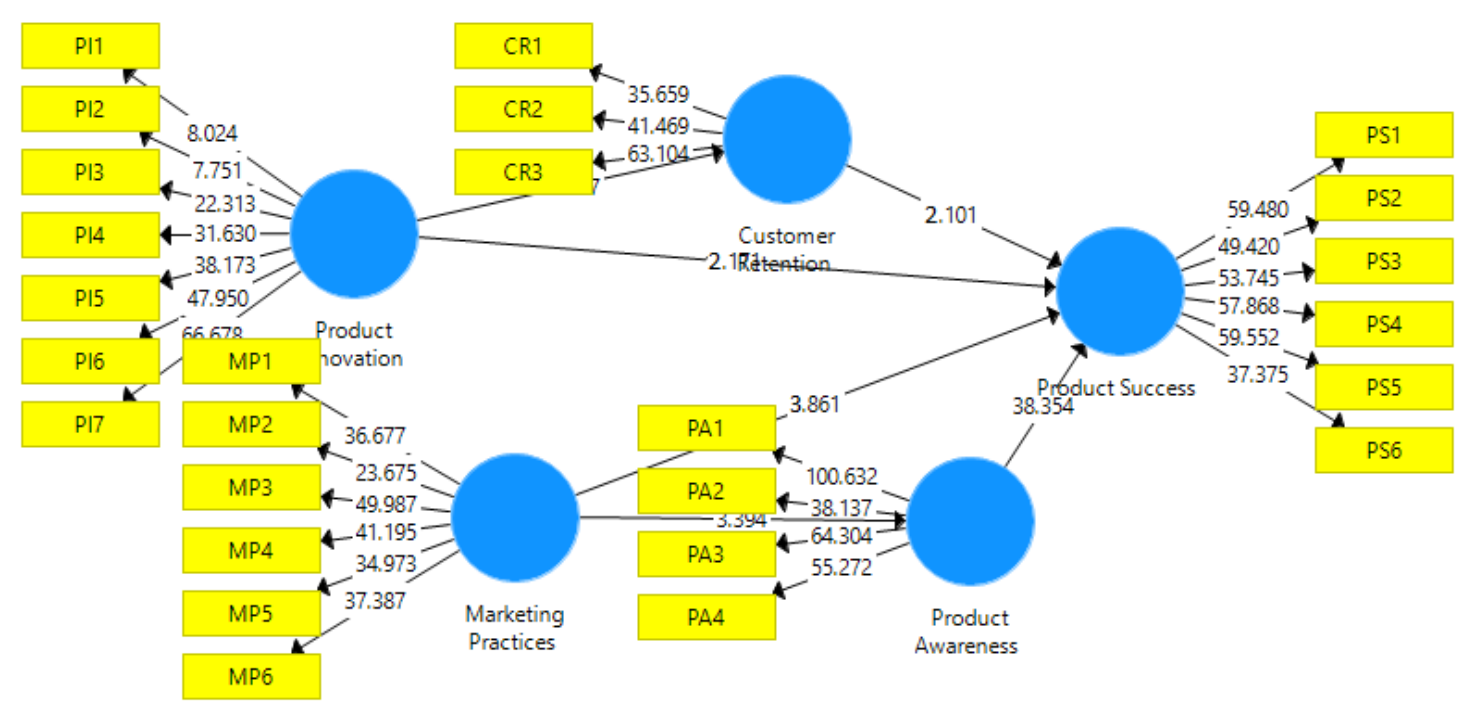

Figure 4. Structural model

Table 5. Direct effect results

\begin{tabular}{lccccc}
\hline & $(\mathbf{O})$ & $(\mathbf{M})$ & SD & T Statistics & P Values \\
\hline Customer Retention -> Product Success & 0.013 & 0.006 & 0.129 & 2.101 & 0.043 \\
Marketing Practices -> Product Awareness & 0.342 & 0.365 & 0.101 & 3.394 & 0.001 \\
Marketing Practices -> Product Success & 0.131 & 0.144 & 0.153 & 3.861 & 0 \\
Product Awareness -> Product Success & 0.939 & 0.941 & 0.131 & 38.354 & 0 \\
Product Innovation -> Customer Retention & 0.919 & 0.92 & 0.018 & 52.077 & 0 \\
Product Innovation -> Product Success & 0.117 & 0.123 & 0.054 & 2.171 & 0.042 \\
\hline
\end{tabular}

Note: PI = Product Innovation; MP = Marketing Practices; CR = Customer Retention; PA = Product Awareness; PS $=$ Product Success

After the direct effect assessment, this study examined indirect effect of customer retention and product awareness. The indirect effect of customer retention was examined between product innovation and product success. Moreover, the indirect effect of product awareness was examined between marketing practices and product success. It is found that customer retention has insignificant effect between product innovation and product success with $t$-value 0.1 . It shows the customer retention is not a mediating variable between product innovation and product success. Furthermore, the indirect effect of product awareness is significant between marketing practices and product success as the $\mathrm{t}$-value is 3.371 . It shows that product awareness is a mediating variable between marketing practices and product success. 
Table 6. Indirect effect results

\begin{tabular}{|c|c|c|c|c|c|}
\hline & (O) & (M) & SD & $\begin{array}{c}\mathbf{T} \\
\text { Statistics } \\
\end{array}$ & $\begin{array}{c}\mathbf{P} \\
\text { Values }\end{array}$ \\
\hline $\begin{array}{l}\text { Product Innovation -> Customer Retention -> Product } \\
\text { Success }\end{array}$ & 0.012 & 0.007 & 0.119 & 0.1 & 0.92 \\
\hline $\begin{array}{l}\text { Marketing Practices -> Product Awareness -> Product } \\
\text { Success }\end{array}$ & 0.321 & 0.343 & 0.095 & 3.371 & 0.001 \\
\hline
\end{tabular}

Note: PI = Product Innovation; MP = Marketing Practices; $\mathrm{CR}=$ Customer Retention; PA = Product Awareness; PS

$=$ Product Success

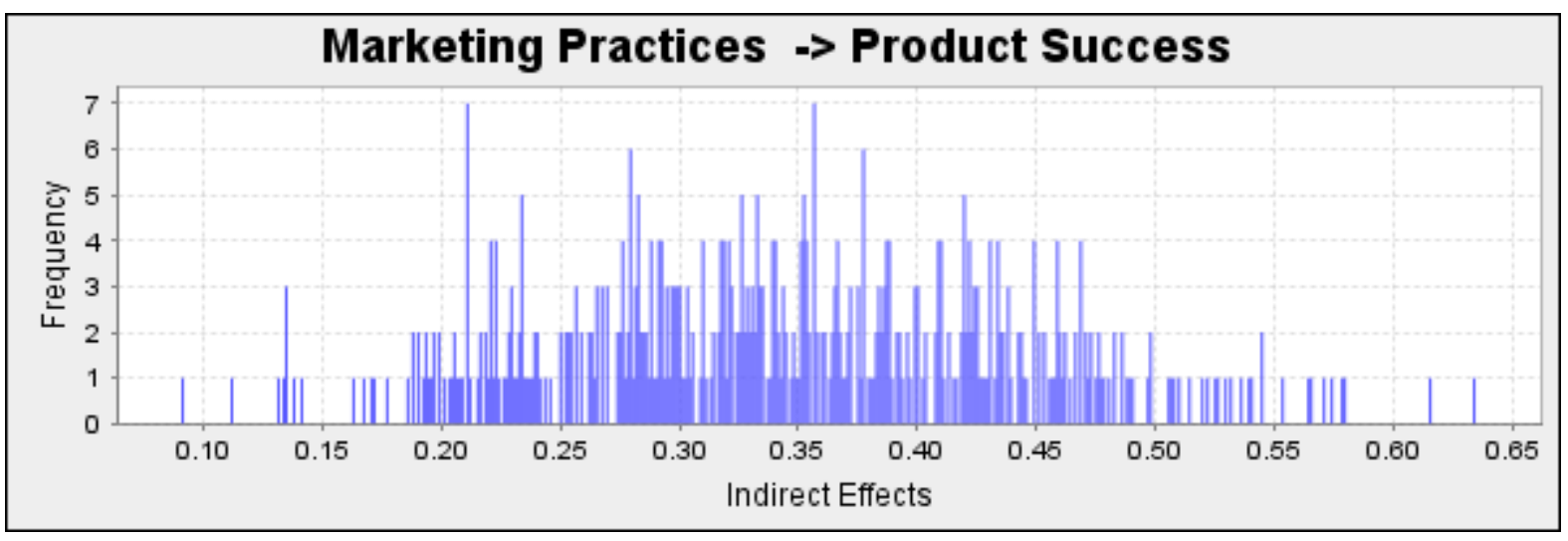

Figure 5. Indirect effect histogram: Marketing practices -> Product awareness -> Product success

\section{Conclusion}

The objective of this study was to investigate the role of product innovation and marketing practices in product success of herbal city community. This study examined the relationship between product innovation, marketing practices, customer retention, product awareness and product success among the herbal companies of Thailand. Population of the study was herbal companies of Thailand. Data were collected from the herbal companies in Thailand.

It is revealed from the data analysis, product innovation has significant effect on product success. Increase in the innovation among company products increases the product success in herbal companies. Moreover, marketing practices also shows positive influence on herbal company's product success. Better marketing practices increases the product success. Therefore, both the product innovation and marketing strategies increases the success of herbal companies' product. Focus of herbal city community on product innovations may increase the rate of success. In this direction, both product innovation and marketing practices has direct effect on herbal companies' success. Furthermore, it is found that product innovation and marketing strategies also has indirect effect on product success. It is found that product innovation has positive effect on customer retention. Increase in product innovation has the potential to increase job satisfaction which has the ability to increase product success. Moreover, it is found that marketing strategies has positive influence on product success through product awareness. Marketing strategies increases the awareness about the product among people which causes to increases the product success. Hence, product innovation and marketing strategies has indirect effect on product success through customer retention and product awareness. Hence, it is found that; both product innovation and marketing practices has significant role to enhance product success. Increase in product innovation and marketing practices increases the product success. Product innovation and marketing practices effect positively on customer retention and marketing practices respectively which causes to increase product success.

\subsection{Implications of the Study}

The current study has several implications for the literature; however, the current study highlighted the main implications having role in various activities. First of all, this study examined the valuable relationship between product innovation, marketing practices, customer retention, product awareness and product success. This is the most vital relationship which has positive contribution to the development of literature. Second, in literature development, 
this study has vital role to investigate the mediating role of customer intention. This study contributed by examining the relationships and proved that product awareness is a mediating variable between marketing strategies and product success. This study also has practical implications. Especially, practical implications have vital role for herbal city community. The herbal companies can enhance the product success by focusing on product innovation and marketing practices. Therefore, by examining the relationship between product innovation, marketing practices, customer retention, product awareness and product success, the herbal companies can enhance the product success. Herbal city community is not discussed in previously in relation to the product innovation and marketing strategies. Therefore, this study is vital role to contribute to the literature of herbal city community. Findings of the study could be beneficial for the management of herbal community in Thailand. It is also quite helpful for the government of Thailand to promote herbal industry.

\section{Limitations of the Study}

Although the current study highlighted the key areas in the concerned field having significant practical as well as theoretical implications, however, the current study has few limitations which could be the most fruitful future directions for the researchers. First, this study used all marketing practices in form of one variable, each marketing strategy one by one is not examined, therefore, future studies should examine all the marketing practices or important marketing practices in the current model. Second, this study could not cover the whole herbal community in Thailand due to shortage of time. The future study should cover all community which may affect on the results. In addition to this, product innovation and marketing practices have strong relationship with each other which is evident from the literature. However, while examining the herbal community, this study has not considered the relationship between product innovation and marketing practices. Hence, future studies should also consider the relationship between product innovation and marketing practices while carrying out research on herbal community. It is important to consider because marketing practices are important to promote product innovation.

\section{References}

Abid, M. F., Gulzar, A., Kolesnikova, J., Zagidullina, V., Valeev, E., Bychkov, G., . . Herawaty, T. (2018). Impact of Strategic Orientation on New Product Success with Mediating Role of New Product Development Knowledge Management Capabilities. RIBER, 7(s4), 1-31.

Ali, G., Naveed, F., ul Hameed, W., \& Rizvi, T. (2018). The Effect of Task Illegitimacy on the Wellness of Employees. UCP Management Review (UCPMR), 2(2), 5-20.

Almohaimmeed, B. (2019). Pillars of customer retention: An empirical study on the influence of customer satisfaction, customer loyalty, customer profitability on customer retention. Serbian Journal of Management, 14(2), 421-435.

Andriyani, I. N., Wibowo, L. A., Novalita, D. P., Rahayu, W. P., Kusumojanto, D. D., Sulistyowati, R., \& Sudarwanto, T. (2017). Dominant Factors Analysis of Customer Perceived Value Which Effect on Customer Retention.

Aydin, D., \& Şenoğlu, B. (2018). Estimating the Missing Value in One-Way Anova Under Long-Tailed Symmetric Error Distributions. Sigma: Journal of Engineering \& Natural Sciences/Mühendislik ve Fen Bilimleri Dergisi, $36(2)$.

Bowling, A., Bond, M., Jenkinson, C., \& Lamping, D. (1999). Short Form 36 (SF-36) Health Survey questionnaire: which normative data should be used? Comparisons between the norms provided by the Omnibus Survey in Britain, the Health Survey for England and the Oxford Healthy Life Survey. Journal of Public Health, 21(3), 255-270.

F. Hair Jr, J., Sarstedt, M., Hopkins, L., \& G. Kuppelwieser, V. (2014). Partial least squares structural equation modeling (PLS-SEM) An emerging tool in business research. European Business Review, 26(2), 106-121.

Falahat, M., Ramayah, T., Soto-Acosta, P., \& Lee, Y.-Y. (2020). SMEs internationalization: The role of product innovation, market intelligence, pricing and marketing communication capabilities as drivers of SMEs' international performance. Technological Forecasting and Social Change, 152, 119908.

Hair, J., Hollingsworth, C. L., Randolph, A. B., \& Chong, A. Y. L. (2017). An updated and expanded assessment of PLS-SEM in information systems research. Industrial Management \& Data Systems, 117(3), 442-458.

Hair, J. F., Ringle, C. M., \& Sarstedt, M. (2013). Partial least squares structural equation modeling: Rigorous applications, better results and higher acceptance. 
Hair Jr, J. F., Hult, G. T. M., Ringle, C., \& Sarstedt, M. (2016). A primer on partial least squares structural equation modeling (PLS-SEM). Sage Publications.

Hameed, W. U., Basheer, M. F., Iqbal, J., Anwar, A., \& Ahmad, H. K. (2018). Determinants of Firm's open innovation performance and the role of R \& D department: an empirical evidence from Malaysian SME's. Journal of Global Entrepreneurship Research, 8(1), 29.

Hamid, S. N. A., Shahid, M. N., Hameed, W. U., Amin, M., \& Mehmood, S. (2019). Antecedents Of Job Stress And Its Impact On Nurse's Job Satisfaction And Turnover Intention In Public And Private Hospitals Of Punjab Pakistan. International Journal of Scientific \& Technology Research, 8(10), 129-137.

Hawrelak, J. A., Wohlmuth, H., Pattinson, M., Myers, S. P., Goldenberg, J. Z., Harnett, J., . . Whitten, D. L. (2020). Western herbal medicines in the treatment of irritable bowel syndrome: A systematic review and meta-analysis. Complementary Therapies in Medicine, 48, 102233.

Henseler, J., \& Fassott, G. (2010). Testing moderating effects in PLS path models: An illustration of available procedures. Handbook of partial least squares (pp. 713-735). Springer.

Henseler, J., Ringle, C. M., \& Sinkovics, R. R. (2009). The use of partial least squares path modeling in international marketing. New challenges to international marketing (pp. 277-319). Emerald Group Publishing Limited.

Lin, Y. C., Huang, C. C., Lin, M. C., \& Huang, S. T. (2020). Chinese herbal medicine reduces the risk of urinary incontinence in patients with chronic obstructive pulmonary disease: A population-based retrospective cohort study. International Journal of Urology, 27(5), 415-422.

Ma, X., \& Cheng, J. (2020). The impact of social insurance contributions on firms employment and wages: Evidence from China employer-employee matching survey data. Asian Development Policy Review, 8(1), 42-60.

Marchand, A., Hennig-Thurau, T., \& Wiertz, C. (2017). Not all digital word of mouth is created equal: Understanding the respective impact of consumer reviews and microblogs on new product success. International Journal of Research in Marketing, 34(2), 336-354.

Marquez, D. R. L., Lingat, A., Silva, M. S. S., Rodriguez, A. A., \& de Vera, O. M. (2020). A descriptive study on the preferences of community members toward utilization of herbal medication compared to synthetic drugs in the National Capital Region, Philippines. Enfermería Clínica, 30, 113-119.

Melesse, W. (2019). Business cycles and financial frictions under money growth rule. Asian Journal of Economics and Empirical Research, 6(1), 16-26.

Mensah, O. S., Jianlin, C., \& Jun, J. Y. (2019). A quantile regression analysis of contributing factors influencing agribusiness growth and entrepreneurship development: Evidence from rural China. Asian Business Research Journal, 4(1), 10-16.

Michaelis, T. L., \& Markham, S. K. (2017). Innovation Training: Making Innovation a Core Competency A study of large companies shows that, although managers see human capital as central to innovation success, most aren't providing innovation training. Research-Technology Management, 60(2), 36-42.

Muhammad Auwal, A., Mohamed, Z., Nasir Shamsudin, M., Sharifuddin, J., \& Ali, F. (2020). External pressure influence on entrepreneurship performance of SMEs: a case study of Malaysian herbal industry. Journal of Small Business \& Entrepreneurship, 32(2), 149-171.

Muzurura, J. (2019). Foreign direct investment in Zimbabwe: The role of uncertainty, exports, cost of capital, corruption and market size. The Economics and Finance Letters, 6(1), 9-24.

Najafi-Tavani, S., Najafi-Tavani, Z., Naudé, P., Oghazi, P., \& Zeynaloo, E. (2018). How collaborative innovation networks affect new product performance: Product innovation capability, process innovation capability, and absorptive capacity. Industrial Marketing Management, 73, 193-205.

Nguyen, A. T. (2020). The relationship between tourism and economic growth: Evidence from oceania. Journal of Tourism Management Research, 7(1), 32-41.

Njegovanovic, A. (2018). Hilbert space/quantum theory of the financial decision and role of the prefrontal cortex with a view to emotions. International Journal of Social and Administrative Sciences, 3(1), 42-54.

Noor, I., \& Siddiqui, D. A. (2019). Evidence of non-linear relationship between non-interest income and profitability of commercial banksin Pakistan. Asian Journal of Economic Modelling, 7(1), 14-26.

Omondi, S. O., \& Odock, S. (2019). Effect of Service Quality on Customer Retention at Branded Night Clubs in 
Mombasa County, Kenya: A Pivotal, Core and Peripheral Attributes Model Perspective. Journal of Marketing and Communication, 2(1), 24-47.

Pferschy-Wenzig, E., Koskinen, K., Roßmann, A., Ardjomand-Woelkart, K., Moissl-Eichinger, C., \& Bauer, R. (2017). Combining LC-MS metabolomics and next generation sequencing to study the interactions between herbal medicines and human gut bacteria in-vitro. Planta Medica International Open, 4(S 01), We-SL-03.

Querbach, S., Bird, M., Kraft, P. S., \& Kammerlander, N. (2020). When the Former CEO stays on Board: The Role of the Predecessor's Board Retention for Product Innovation in Family Firms. Journal of Product Innovation Management.

Razzaq, S., Maqbool, N., \& Hameed, W. U. (2019). Factors Effecting The Elasticity Of Micro Credit Demand In Southern Punjab, Pakistan. International Journal of Social Sciences and Economic Review, 1(2), 46-53.

Richter, K., \& Walther, J. (2016). Supply Chain Integration Challenges in Commercial Aerospace: A Comprehensive Perspective on the Aviation Value Chain. Springer.

Rothaermel, F. T., Hitt, M. A., \& Jobe, L. A. (2006). Balancing vertical integration and strategic outsourcing: effects on product portfolio, product success, and firm performance. Strategic management journal, 27(11), 1033-1056.

Shahmohammadi, M., \& Khanaposhtani, G. F. (2016). A Study of the Factors Affecting the Development of the Portfolio of Products of the Iranian Top Pharmaceutical Companies Using Promethee Method. Mediterranean Journal of Social Sciences, 7(3 S3), 329-329.

Siuly, Li, Y., \& Wen, P. (2011). EEG signal classification based on simple random sampling technique with least square support vector machine. International journal of Biomedical Engineering and Technology, 7(4), 390-409.

Souder, W. E., \& Song, X. M. (1997). Contingent product design and marketing strategies influencing new product success and failure in US and Japanese electronics firms. Journal of Product Innovation Management: An International Publication of the Product Development \& Management Association, 14(1), 21-34.

Suki, N. M., \& Suki, N. M. (2019). Correlations between awareness of green marketing, corporate social responsibility, product image, corporate reputation, and consumer purchase intention. Corporate Social Responsibility: Concepts, Methodologies, Tools, and Applications (pp. 143-154). IGI Global.

Sürücü, Ö., Öztürk, Y., Okumus, F., \& Bilgihan, A. (2019). Brand awareness, image, physical quality and employee behavior as building blocks of customer-based brand equity: Consequences in the hotel context. Journal of Hospitality and Tourism Management, 40, 114-124.

Tundung, S. P., Ludfi, D., \& Hanif, M. (2017). The Relationship Between Knowledge Management Capabilities and Product Innovation and Its Impact on Marketing Performance. Paper presented at the 2nd International Conference on Accounting, Management, and Economics 2017 (ICAME 2017).

Walton, B., Petrovici, D., \& Fearne, A. (2017). Factors Impacting the Success of new Product Development in the UK Grocery Retail Industry: An Empirical Examination of Product Innovation Performance. The Customer is NOT Always Right? Marketing Orientationsin a Dynamic Business World (pp. 182-185). Springer.

Wu, L.-L., Joung, Y.-J., \& Lee, J. (2013). Recommendation systems and consumer satisfaction online: moderating effects of consumer product awareness. Paper presented at the 2013 46th Hawaii International Conference on System Sciences.

\section{Copyrights}

Copyright for this article is retained by the author(s), with first publication rights granted to the journal.

This is an open-access article distributed under the terms and conditions of the Creative Commons Attribution license (http://creativecommons.org/licenses/by/4.0/). 